\title{
Hypothalamic Neoplasm
}

National Cancer Institute

\section{Source}

National Cancer Institute. Hypothalamic Neoplasm. NCI Thesaurus. Code C3129.

A primary or metastatic neoplasm that affects the hypothalamus. 